p. 308

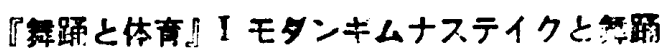

\section{その 2 モダンギムナステイクの実態}

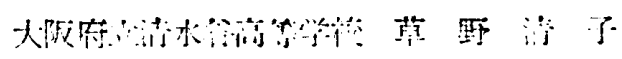

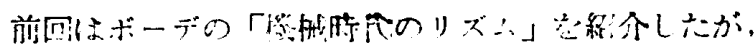

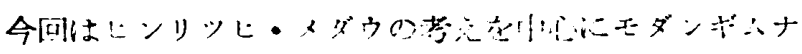

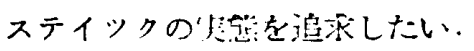

「モダンギムナスティック（以下 MG と略）とは何 か、リギムは何を垔さか？」といら講演の中でィダウは 次のよらに述べている。

『MG は専ら動きの数育であり，トルネンやスボーツ と全く夙㳼に男子にも文子にも而てはまる．MGは人 闍のあらゆる動きは有機的な性格を持つているというこ

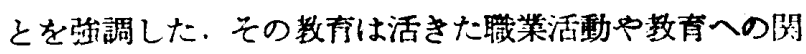
条を持たなかつたこれまでの徒手㷊㙅の原理の全くの反 対侧にある.MG はトルネンむスポーツをも自身の枠

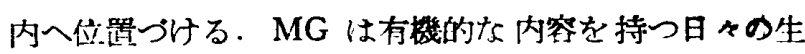
活を深める要求である.』と・（一メダウの分ち書きを した部分，以下同じ）

ギムナスティクの語及びその内容の変遼につい・ては40 年前には

○ギムナステイツクの語はドイッ国内で用いられて いなかつた。

○用いられたとしてもあるスポーツの準備運動とし てであつた.

○トルネンの中での秩序と姿栵の形成がギムナステ イクと言われ

○芸術舞踊に於ける技術の練漗が舞踊的ギムナステ イクと呼ばれたりした。

その後「真のギムナステイクの集りとも称すべき集り が女子のための全く新しい身体教育を生み出した. 東洋 からの剌㦸により，呼吸法の練習と原理を研究し呼吸調 整を人閏教育の中核となした。このGが初期から全面的 な賛同を得たのでは决して無いし，今日でも完全な理解 を得ているとは言い䧿い，身体数育の目的は今日佮立派 な成果であつてすべてがこれに関連させられるために， 女性らしい優美さには䦭心のない奔放なスポーツ女性の タイプがたやすく現れることになる，身体威情，洹動感

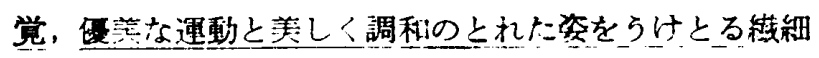

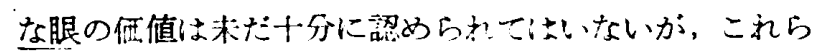

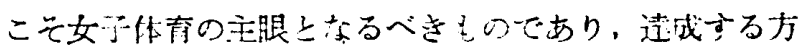

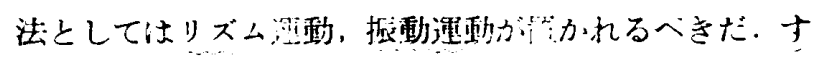

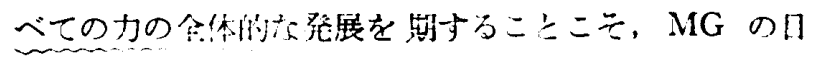

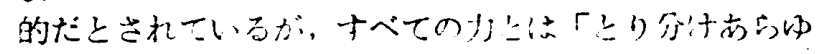

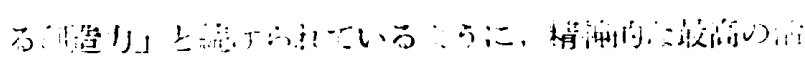

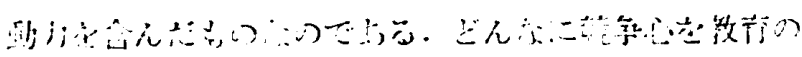

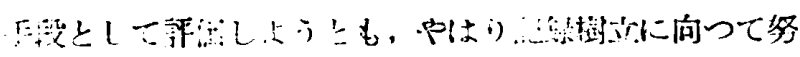

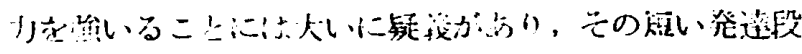

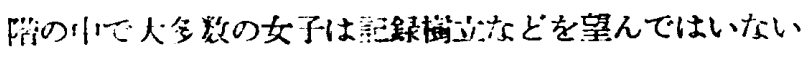
とメダウは述べる，記睩が樹立されていることはあ万 うとす。それはシールではなく結果に過きない，のた。 しかるスポーッが他の種日では代替しえない独自性によ つて興路したと同㥞にギムナステイクも何物によつて る代用しえぬ独自性を考知すべきだ．梓技のためにでは なく平和の 合一のためにリギム（国绦ギムナステイク 連㓵）の基礎づけられた意義もこつにある.

男子の体有への影嘌としては，リズム的，音楽的な面 を覃かにすることがあげられる。

以上采知の MG の発展の释過，そしてその存立の意 義であるが，他の表現をかりてこれを略記したい．

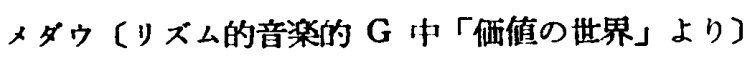
現代分明の危譏は

人閌の二面性の中, 㒛識, 知性の面のみ強化に より招来された。

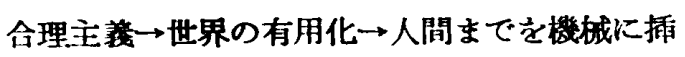
入された事物と見る。

人間の他の一面（神との関連の中にある自己）の 発胃. 自然, その創造物，とり分け人間への畏 教、創造への宗教的畏教を見出すことにより，は しめて全人としての人間完成がある．この方法が 「リズム的音染的G」である.

ラハンン〔生きているェネルギーのリズム」より)

。生命は他の自然現象と同様にリズムを持つてい 子.

○よくリズムを持つたエネルギーは知性と善意に閣 係ある努力をする.

。運動の法則を知り、これに精通することは人間の 本性が自由になるために，本買的に必要なことで ある・

ハンス・フルフト〔言語反㱖に於ける運動の本厝よ り)

○あらゆる生物には生の脈動が感得できる。てれは 大抵呼吸に㤋て認識しうる，

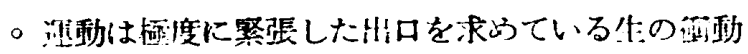

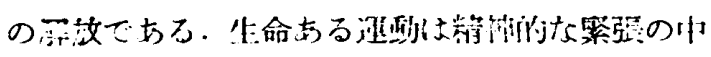

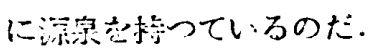

